\title{
The International Ceramics Trade and
} Social Change in the Red River Delta in the Early Modern Period

\section{A Case Study of Bát Tràng and Kim Lan Villages}

\author{
Ueda Shinya \\ Visiting Fellow, Osaka University, Japan \\ uedashinya_vnjp@yahoo.co.jp \\ Nishino Noriko \\ Foundation to Safeguard the Underground Cultural Heritage in Southeast Asia, \\ Japan \\ norikonishino@gmail.com
}

\begin{abstract}
Nishimura Masanari argued that the construction of enclosed-type levees caused the water level of the Red River to rise in seventeenth-century northern Vietnam, and he suggested that this phenomenon triggered social changes that brought about the establishment of Vietnamese "traditional society," represented by the autonomous villages of the Red River Delta. Nishimura's archaeological discussion of the transition from horseshoe-shaped levees to enclosed-type levees suggests new ways of studying socioeconomic change in early modern Vietnam. This article examines the utilization of the dry riverbed area of the Red River near Hanoi and tracks changes in the position of the levee near the neighboring villages of Bát Tràng and Kim Lan from the seventeenth century onward. The article shows that Nishimura's argument concerning the levee network makes it possible to locate the establishment of early modern Vietnamese society in the "Age of Commerce."
\end{abstract}

\section{Keywords}

Age of Commerce - Annam - Bat Trang - dry riverbed - horseshoe-shaped levee Kim Lan - Red River Delta - Wada Rizaemon 


\section{Introduction}

The Red River Delta in Northern Vietnam combines primary landscapes with artificial levees and the surrounding swampland. This region was frequently submerged during the summer rainy season and was developed as a wet-rice cultivation area through the utilization of abundant water resources. Flood control and the maintenance of a water supply for a stable wet-rice agriculture have been important concerns for successive Vietnamese dynasties and people. The present-day Red River Delta is occupied by many large-scale polders that are enclosed by levees, and we may assume that this levee network has a long history. Sakurai Yumio has shown in his studies that the construction of this levee network began during the fourteenth-century Trần Dynasty and was mostly complete by the time of the Restored Lê Dynasty (Lê-Trịnh government) in the seventeenth and eighteenth century. ${ }^{1}$ Sakurai's argument is based on the premise that these horseshoe-shaped levees opened in the direction of the lower branch of the Red River in order to drain off levee water into the ground. However, as Nishimura has indicated, there was a gap in technological evolution between horseshoe-shaped levees and enclosed-type levees, although both are definitely present during the nineteenth-century Nguyễn Dynasty. ${ }^{2}$ The authors propose that transitions from horseshoe-shaped levees to enclosed-type levees occurred during the seventeenth and eighteenth century.

Nishimura's argument acknowledges this problem, and shows that the areas of elevated land and inhabited villages in the Red River Delta expanded, particularly in the seventeenth century. He suggested that the expansion was caused by a rise in the Red River's water level due to the construction of an enclosed-type levee network. ${ }^{3}$ According to Nishimura, the construction of an enclosed-type levee network caused the water levels of the Red River and its branches to rise, due to the reduction of the size of the retarding basin and the acceleration of sediment deposition in the riverbed. At the same time,

1 Sakurai Yumio, "A Preliminary Essay on the Reclamation in the Ancient Red River Delta," Southeast Asian Studies 17, no. 1 (1979): 3-57; idem, "The Red River Delta in the Tenth Century," Southeast Asian Studies 17, no. 4 (1980): 597-632; idem, "The Red River Delta during Ly Dynasty (1010-1225)," Southeast Asian Studies 18, no. 2 (1980): 271-314; idem, "The Red River Delta in the Tran Dynasty (1225-1440) I," Southeast Asian Studies 27, no. 3 (1989): 275-300; idem, "The Red River Delta in the Tran Dynasty II," in Historical Phases of Southeast Asia, ed. Ishii Yoneo et al. (Tokyo: University of Tokyo Press, 1992), 21-45.

2 Nishimura Masanari, Archaeology and Ancient History of Vietnam (Betonamu no KokoKodaigaku) (Tokyo: Dosei-sha, 2011), 279.

3 Ibid., 294-295. 
the elevation of the residential area along the river increased, and new villages were established on the ground enclosed by the levee. Nishimura's argument is not only important for Vietnamese technological history, but also very suggestive for socioeconomic history, as this period overlaps with the formative period of Vietnamese "traditional society" as represented by the autonomous villages of the Red River Delta. ${ }^{4}$ In fact, a large number of inscriptions and historical documents owned by the Han Nom Institute show that during this period various religious facilities, including communal village halls, ancestral shrines, and so on, were built and repaired, and also that there was an explosive increase in local documents written by villagers. ${ }^{5}$ There are both social and documentary differences between the periods before and after the seventeenth century. After the seventeenth century, a particular group of people appeared on the front stage of history as the main actors in the documentary record, suggesting that various social connections and social groups, such as village communes, agnate kin groups, and so on, gained power rapidly during this period. However, historians studying letters written during that period have not made enough progress to be able to describe the socioeconomic background of these groups. Nishimura's archaeologically grounded argument points to the importance of using other methods for examining socioeconomic change. Building on Nishimura's argument, this article examines the utilization of the dry riverbed area around the Red River near Hanoi and tracks changes in the position of the levees near the neighboring villages of Bát Tràng and Kim Lan (Figs. 1-2).

\section{The Establishment of Bát Tràng and Kim Lan Villages}

Reliable historical records do not offer precise details about the founding of Bát Tràng and Kim Lan villages. A tradition associates the origins of Kim Lan village with Cao Biền (高駇, d. 887), Protector General to Annam of the Tang Dynasty, and two of his vassals, Trạc (濯) and Chử (褚), who were all enshrined in the village. A document written by Nguyễn Bính (阮炳) in the Mạc Dynasty

4 Sakurai Yumio, Formation of Vietnamese "Traditional" Villages: Historical Development of Communal Land in Northern Vietnam [Japanese] (Tokyo: Sobun-sya, 1987).

5 Concerning the formation of agnate kin groups, see Ueda Shinya, "The Formation of Village Society and Kinship Groups in the Environs of Hue, Vietnam: The Case of Thanh Phuoc Village from the 18th to the 19th Centuries," Journal of Oriental Researches 73, no. 1 (2013): 100-136. 


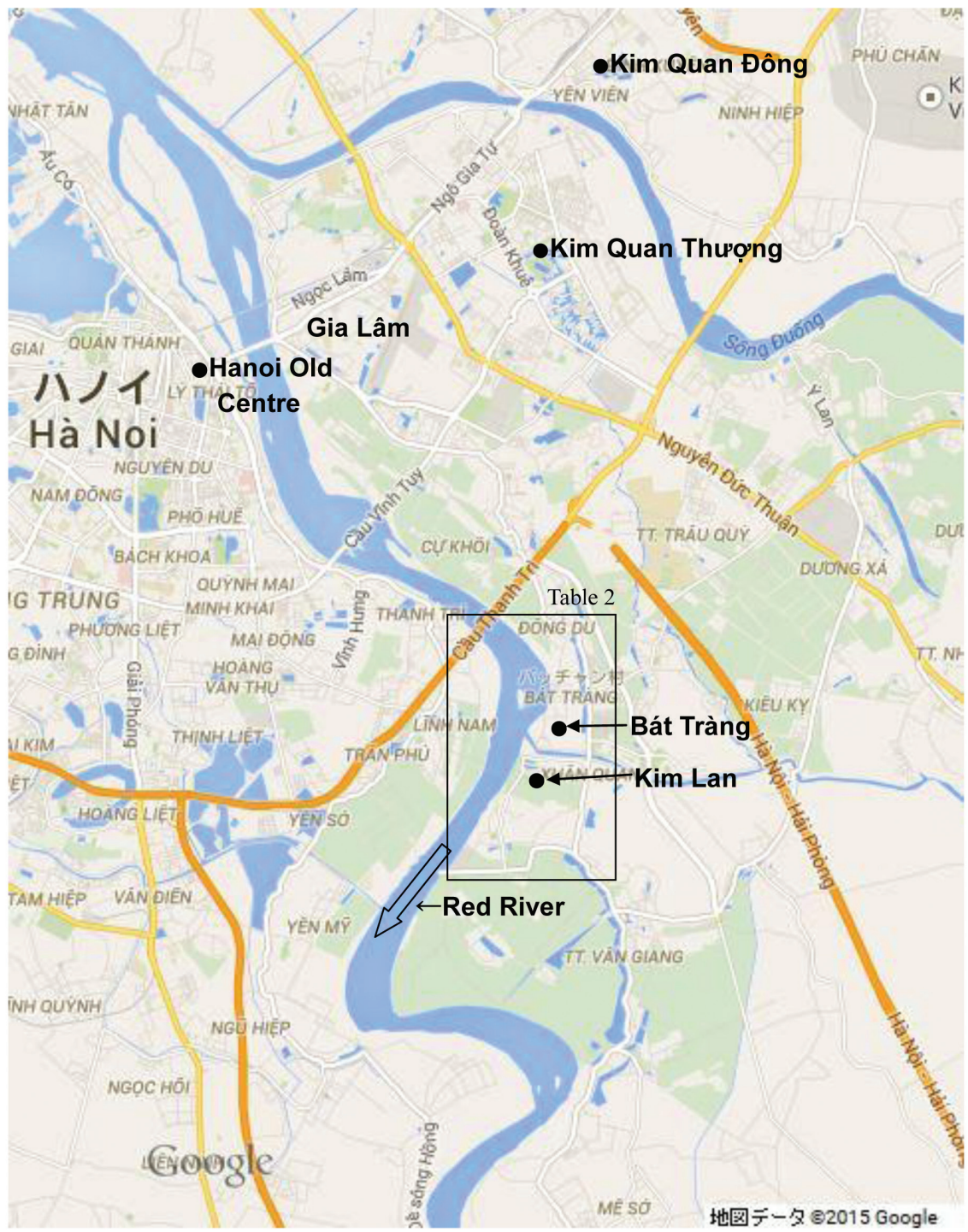

FIGURE 1 Bát Tràng and Kim Lan and environs. MAP SOURCE: GOOGLE MAPS. 
A line : Trần dynasty period? 1640s

B line : 1640s 1830s

$\mathrm{C}$ line : Present Levee

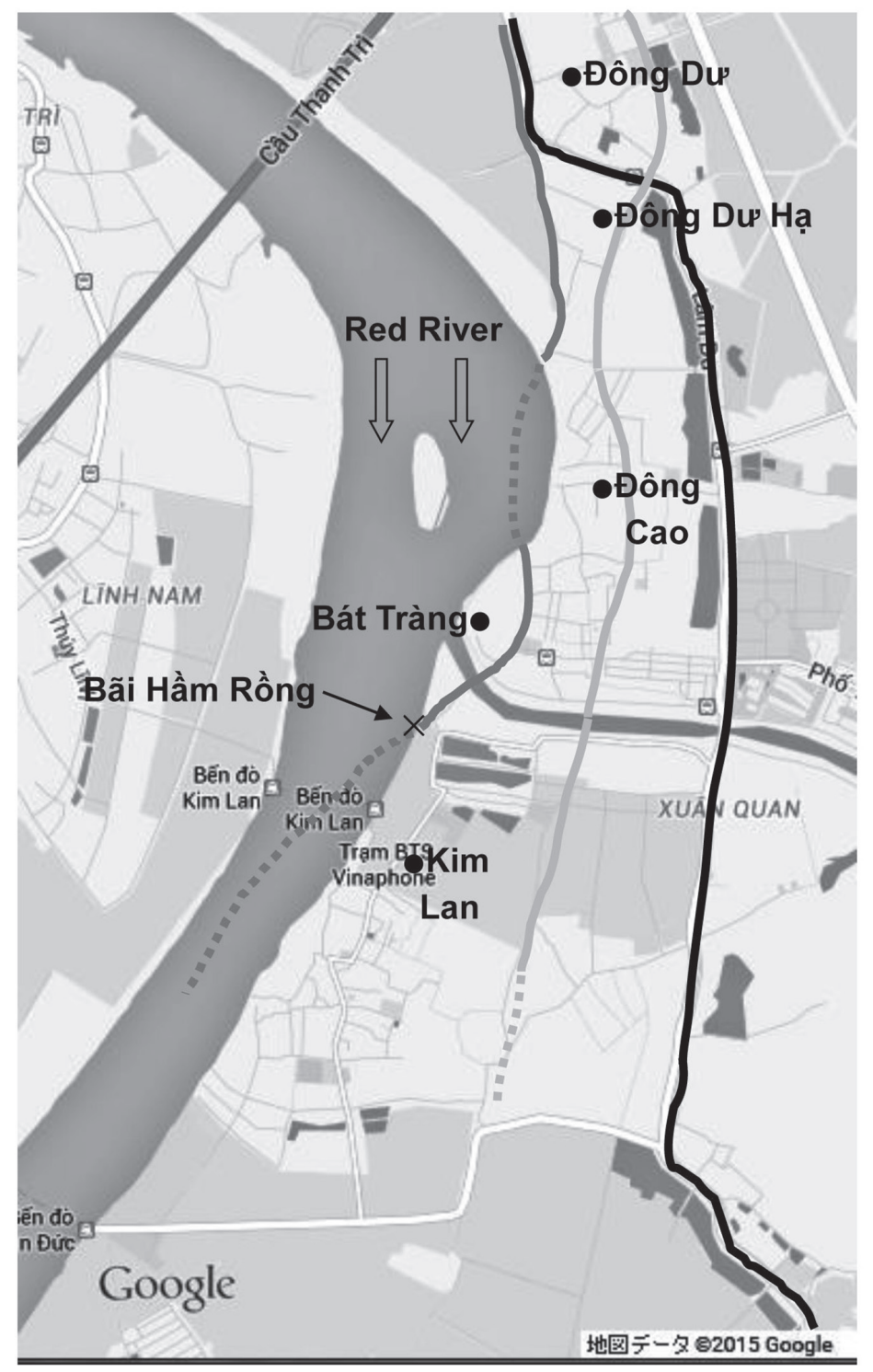

FIGURE 2 Changes in the position of the levee with respect to the neighboring villages of Bát Tràng and Kim Lan.

MAP SOURCE: GOOGLE MAPS. 
era explains the origin of these three deities. ${ }^{6}$ When Cao Biền was boating on the Red River, he spotted a location that his study of Chinese geomancy indicated was favorable, and he ordered Trạc and Chử to build his villa there. This was the origin of Kim Lan village. If this document is reliable, Kim Lan village was established in the ninth century. Interestingly, the results of the excavation of Bãi Hầm Rồng by Nishimura and Nishino show that pottery was produced at Kim Lan village in the ninth century, which indicates that Kim Lan village was established around the ninth century. It is noteworthy that this village was involved in pottery manufacture from its early days. ${ }^{7}$

On the other hand, Bát Tràng village makes its first appearance in the historical record in 1376, in a government-compiled document. When Trần Duệ Tông (r. 1373-1377) made an expedition to Champa, he passed through Bát xã (鉢社) on his way. Therefore, it is certain that Bát Tràng village had been founded before the last quarter of the fourteenth century. However, in their family genealogies, edited in the nineteenth century, some members of the clan of Bát Tràng village insisted that the village dated back to the Lý Dynasty, which would imply that Bát Tràng village was founded in the eleventh or twelfth century. ${ }^{8}$ Unfortunately, information on the Nguyễn clan prior to the fifteenth century was lost in the late seventeenth century. It is doubtful that there was a clan connection based on Confucianism before the fifteenth century. At present, the history of this village before the thirteenth century remains unknown.

An area for pottery manufacture was established on the east bank of the Red River in Bát Tràng and Kim Lan villages in the fourteenth century, but there is no information about the establishment of pottery villages before the fourteenth century. Hence, it is difficult to analyze because of the changes of location. Both of the villages are positioned on the dry riverbed of the Red River, whereas the changing course of the river has led to the frequent formation and destruction of useable land. The levees also influenced the river's course;

6 北寧省嘉林縣金關社神蹟 Băc Ninh tỉnh Gia Lâm huyện Kim Quan xã Thần tích (The Gods of Kim Quan Commune, Gia Lam Prefecture, Bac Ninh Province), AD.A7/13, Han Nom Institute.

7 There is a possibility that this pottery is from Bát Tràng village (its old name was Bạch Thổ phường 白土坊) from the Lý and Trần dynasties. However, we cannot be certain because its territory is not known.

8 For example, 陳族譜記 Trần tộc Phả ký (in Viện Việt Nam học và Khoa học Phát triển) states that their progenitor migrated from Ninh Bình Province into Bát Tràng village in the Lý Dynasty period. 北寧嘉林鉢場陳族譜系Bắc Ninh Gia Lâm Bát Tràng Trần tộc phả hệ (in Viện Việt Nam học và Khoa học Phát triển) states that their progenitor migrated from Thanh Hóa Province with the Lê clan, the Phạm clan, and the Nguyễn clan during the fifteenthcentury Lê Dynasty. These genealogies were edited in the twentieth century. 
they were repeatedly constructed and abandoned over a long time, and their location could have changed by several hundred meters each time. On the periphery of Bát Tràng and Kim Lan villages, changes in the levee position can be illustrated by the documentation of a lawsuit carved on an inscription in the eighteenth century, and the land cadaster edited in the early nineteenth century by the Nguyễn dynasty (Fig. 2). ${ }^{9}$ On the basis of these documents, the authors surmise that the levee on the A line is the oldest one, and that it existed until the early seventeenth century. When a new levee was built on the $B$ line in the 1630s-40s, the old levee was abandoned. In the land cadaster of the Nguyễn Dynasty, the abandoned levee was recorded as a "former levee" (舊堤) or as the "wreck of the levee" (殘堤). The construction date of the oldest levee is unknown, because its remains have not been excavated. According to Sakurai Yumio, the construction of a large-scale levee network in the Red River Delta began during the Trần Dynasty. Government-compiled documents confirm that a levee already existed on the periphery of Bát Tràng and Kim Lan villages from Bát Tràng village to Thổ Khối in $1352 .{ }^{10}$ Therefore, the levee on the A line was built in the Trần Dynasty.

The neighboring villages of Bát Tràng and Kim Lan built levees from at least the fourteenth century, which suggests that both villages were located beside the Red River. This location is advantageous for producing pottery because pottery villages always need to collect clay, import fuel, and export products. In addition, the location was strongly determined by the Red River's flooding pattern. The eastern riverbank beside the two villages is an undercut slope of the Red River with a southwestern direction. Therefore, the outskirts of the two villages were always in danger of being eroded by the current of the Red River, which was creeping eastward. In fact, a strip of land around 100-200 meters wide that belonged to the two villages was swept away by the Red River during flooding in the 196os. ${ }^{11}$ In the premodern period, the riverside area of the two villages was probably located at least several hundred meters (or more) further west than it is now. Villagers in the premodern period also recognized

For further details, see Ueda Shinya, "The Local Administration of the Lê-Trịnh Government in the 17th-18th Century Vietnam: An Example of Bat Trang Village," in Local Administration and the Maritime World of Early Modern East Asia, ed. Yamamoto Eishi (Tokyo: Kyuko-syoin, 2010), 250-256.

10 Chen Chingho (collation), 校合本大越史記全書 Đại Việt Sủ̉ ký Toàn thú (Collation Version) (hereafter: Toàn thu') (Tokyo: Institute for Advanced Studies on Asia, University of Tokyo, 1985), 425 .

11 Nishimura, Archaeology and Ancient History of Vietnam, 263-264; Ueda Shinya, "Local Administration," 251 . 
that their land was unstable. According to the genealogy of the Nguyễn clan in Bát Tràng village, Nguyễn Thượng (阮尚, 1678-1736) was afraid that the ground around the village's wharf was being eroded, and he appealed to villagers to participate in riverbank protection works in 1723 . He gathered public funds and bought timber, but his undertaking failed due to insufficient funds. Thus, on the one hand, the location of the villages along the river created easy access to materials and facilitated the transportation of pottery; on the other hand, the villages stood on unstable land.

These topographical factors had a powerful effect on life in Kim Lan village. According to the excavations in Kim Lan village, evidence of pottery manufacture disappeared in the fifteenth century, and the production of copper ingots from copper scraps began in the sixteenth century. It is uncertain what prompted this change, but there are some clues. According to the genealogy of the village deity in Kim Quan Thượng, this village was originally a State Farm Station called Kim Quan sở (金關所), which was located in the neighboring Kim Lan village. In the fifteenth century, Kim Lan village was placed within the State Farm Station called Kim Quan sở by Lê Thánh tông (r. 1460-1497). Nishimura presumed that this station was located between present-day Bát Tràng village and present-day Kim Lan village. However, the villagers migrated to the present location to avoid the terrible flooding in 1498-1503 (see Figs. $1-2),{ }^{12}$ and it is possible that the riverbank around Kim Lan village was so seriously damaged by flooding that Kim Lan abandoned pottery production at the end of the fifteenth century. ${ }^{13}$ Meanwhile, sericulture on the dry riverbed became popular from the late fifteenth century onward. Governmentcompiled documents show that from the 1470 s onward, the Lê Dynasty rapidly expanded a taxation system that recognized the importance of sericulture. For instance, Lê Thánh tông enacted laws taxing mulberry fields on the riverbank in 1470,1471 , and $1477 \cdot{ }^{14} \mathrm{He}$ also enacted a law permitting the payment of tax in silkworms in $1497 .^{15}$ Lê Hiến tông, the successor of Lê Thánh tông, also promulgated a statute permitting the payment of tax in raw silk in $1498 .{ }^{16}$ According

\footnotetext{
12 Nishimura, Archaeology and Ancient History of Vietnam, 263-264.

13 According to Toàn thu', nearby Hanoi was damaged by large-scale flooding in 1491; whether the flooding resulted in the migration from Kim Quan sở is uncertain, because the neighboring village Kim Quan and its opposite bank frequently suffered levee crevasses. Chen Chingho, Toàn thu', 738 .

14 See the following historical documents: 歷朝憲章類誌 Lịch triều Hiến chương Loại chí 29 (Tokyo: Toyo bunko, X-2-38), 34; Article of the first year of Hồng Đức (1470); Chen Chingho, Toàn thu', 688, 703 .

15 Ibid., 749 .

16 Ibid., 757 .
} 
to Lịch triều Hiến chương Loại chí, this series of statutes allowed the villages on the dry riverbed to pay tax either in raw silk or in copper coins. ${ }^{17}$ This taxation system for riverside villages was continued by the Lê-Trịnh government.

In fact, inscriptions show that Đông Cao village, located to the northeast of Bát Tràng village, paid its taxes in raw silk. ${ }^{18}$ And the land cadaster of Kim Lan village in the early nineteenth century shows that many mulberry trees were planted in this village. ${ }^{19}$ Historical sources do not record when the villages surrounding Bát Tràng began practicing sericulture, but the genealogy of the Kim Lan village deities describes Cao Biền and his vassals bringing their weaving skills when they established Kim Lan village. ${ }^{20}$ Moreover, a Chinese man named Nguyễn Thạch Việt (阮石越) and his wife were described as moving from Guangxi to Kim Lan village in the late twelfth century. In Kim Lan, this man became a Buddhist priest, and his wife became a weaver. Years later, Nguyễn Thạch Việt passed the examination for service in Lý Cao tông (r. 1173-1210) and contributed to the suppression of the revolt of Phạm Du (范猷). After Nguyễn Thạch Việt's death, he was deified as Kim Lan village's deity. If this account is true, Kim Lan village began to participate in sericulture in the twelfth century. In any case, this genealogy shows a long history of weaving, whereas the precise date of the beginning of sericulture in Kim Lan village is unknown, because this document was written during the Mạc Dynasty. Iioka Naoko has also shown that sericulture developed on the dry riverbed around the banks of the Red River when international trade was growing in the "Age of Commerce."21 It is likely that this village shifted to sericulture after the pottery area of Kim Lan village was severely damaged by flooding in the fifteenth century, and thus benefited from the international commodification of raw silk. If this is indeed the case, then the parts of the Red River dry riverbed that were not favorable to rice-growing were rapidly developed for sericulture in response to the international commodification of raw silk. ${ }^{22}$

17 Lịch triều Hiến chương Loại chí, 29, 34.

18 Inscription N.3525-N.3528, Han Nom Institute, Hanoi.

19 金關社地簿Kim Quan xã địa bạ, Trung tâm Lưu trũ̃ quốc gia I, Q.2516, Han Nom Institute, Hanoi.

20 北寧省嘉林縣金關社神蹟 Bắc Ninh tỉnh Gia Lâm huyện Kim Quan xã Thần tích, AD. A7/13, Han Nom Institute, Hanoi.

21 Iioka Naoko, "The Trading Environment and the Failure of Tongking's Mid-SeventeenthCentury Commercial Resurgence," in The Tongking Gulf through History, eds. Nora Cooke, Li Tana, and James A. Anderson (Philadelphia: University of Pennsylvania Press, 2011), $117^{-132 .}$

22 Regarding this issue, many questions remain unanswered. It is possible that Kim Lan villagers abandoned their village and migrated to Kim Quan Đông village in the fifteenth 


\section{The Development of Bát Tràng Pottery Village}

The custom of the Japanese tea ceremony spread rapidly among the Samurai class from the end of the sixteenth century onward. Vietnamese ceramics were valued highly as precious tea utensils and were called An-nan (安南). Today, about sixty pieces of An-nan ceramics once owned by feudal lords of the Tokugawa Shogunate period remain in Japan. However, until recently, the precise age of these Vietnamese ceramics had not been established for the sake of examining the trade and production of tea ceremony ceramics. Previous studies have identified the year of production of these ceramics within a range of one or two centuries. ${ }^{23}$ Nishimura and Nishino comprehensively analyzed materials collected from the surface of the ground, both within and outside Vietnam, and proposed a new, more precise chronology that places the production date of Vietnamese ceramics within a range of twenty-five to fifty years. ${ }^{24}$ Based on this new chronology, Nishino developed a typology of Vietnamese ceramics in Japan, such as tea utensils. Figure 3 summarizes the results of this examination.

As shown in Figure 3, ceramics produced in the fourteenth and fifteenth century were likely to be purchased from Vietnam by the Japanese as tea utensils after Vietnamese ceramics, known as "An-nan ceramics," became highly valued in seventeenth-century Japan. In the mid-sixteenth century, Vietnamese ceramics were concentrated in southwestern Japan, where Japanese pirates

century, and that the inhabitants of the current Kim Lan village are people who newly remigrated from Kim Quan Đông village or another village after the sixteenth century. If so, we must investigate the long history of the kin groups of current Kim Lan inhabitants in the village, and the relationship between the kin groups of Kim Lan and the kin groups of Kim Quan Đông. However, our investigation does not address this issue.

23 Matsuoka Tadanari and Nishida Hiroko, "Ceramics of Southern Sea and Japan," in Ceramic Art of the World, vol. 16, Southeast Asia, ed. Mikami Tsugio (Tokyo: Shogaku-kan, 1984), 236-253; Nishida Hiroko, Nanban and Shimamono-Exported Southeast-Asian Ceramics for Japan, 16th-17th Century (Tokyo: Nezu Institute of Fine Arts, 1993), 109-124; Hayasiya Seizou, "A Historical Survey of International Intercourse seen in Ceramic Tea Utensils," Toyo Togi 25 (1995-1996): 39-47; Louise Allison Cort, "Vietnamese Ceramics in Japanese Context," in Vietnamese Ceramics: A Separate Tradition, eds. John Stevenson and John Guy (Chicago: Art Media Resources, 1997), 63-83; Akanuma Taka, Inherited Tea Utensils from Southeast Asian Countries [Japanese] (Kyoto: The Urasenke Chado Tradition, 2002), 150-159.

24 Nishimura Masanari and Nishino Noriko, "Techno-morphological Classification and Its Chronological Sequence of the Vietnamese Ceramics from the 1oth to 2oth Century," The Journal of Sophia Asian Studies 23 (2005): 81-122. 


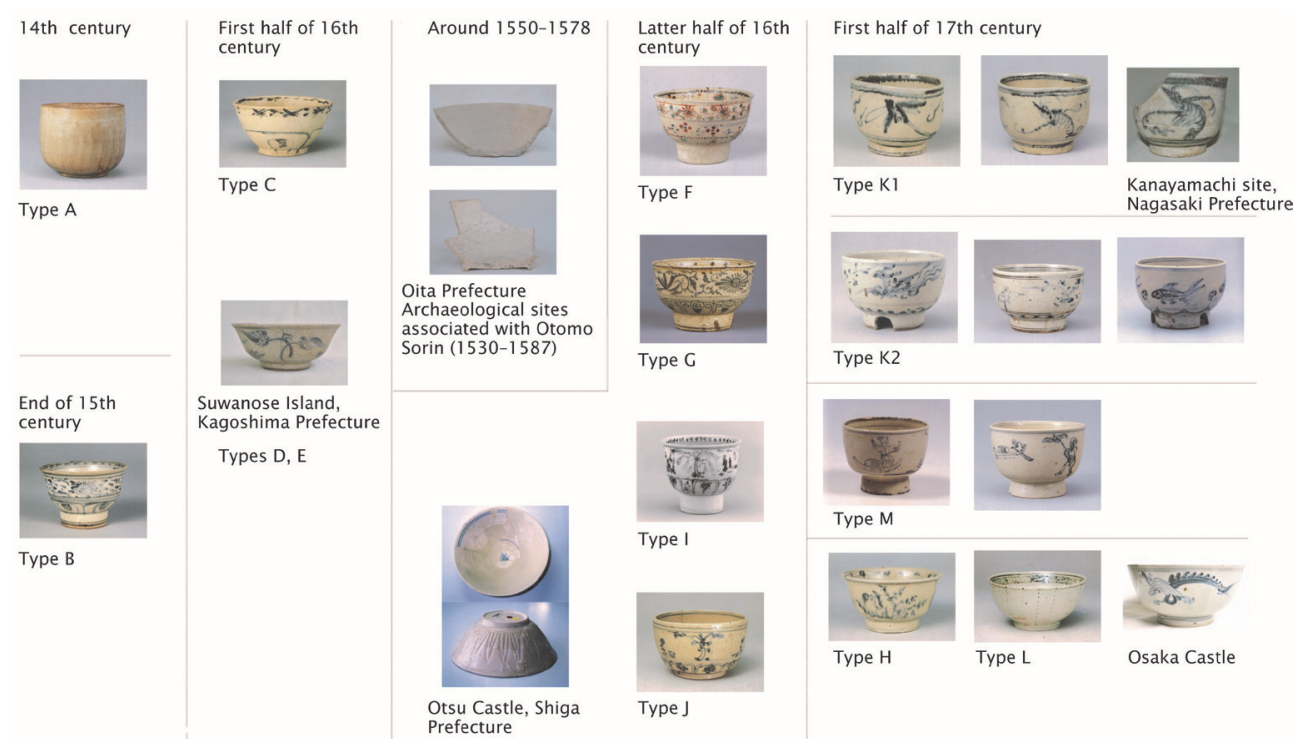

FIGURE 3 Typology and chronology of Vietnamese tea bowls exported to Japan and excavated there.

operated a private import business. ${ }^{25}$ It is possible that this trade resulted in the small-scale distribution of Vietnamese ceramics in that region alone. These ceramics probably had been used as tea utensils in the region before they became highly valued as "An-nan ceramics" elsewhere. Soon after, private trade expanded with the participation of the Portuguese in the coastal areas of Guangdong and Fujian Provinces, leading to increased private trade and smuggling along the coast of the Shuangyu Islands near Ningbo and the Zhoushan Islands, and the activity of the Japanese pirates increased.

Thus, on the international level, Vietnamese ceramics were gathered and transported to Japan in the late sixteenth century, and a considerable number of these ceramics were brought to Japan as tea utensils. During this period, preferences for tea utensils among masters of tea ceremonies underwent a large cultural change. The wabi-cha form of the tea ceremony, founded by Senno-Rikyu, rapidly spread through the governing class, and around 1586 there was a shift in taste: tea utensils from Japan and Korea were preferred over

25 Nakazima Gakusho and Momoki Shiro, "Eastern and Southeast Asia in 'Age of Commerce,"” in A Primer of Maritime Asian History, ed. Momoki Shiro (Tokyo: Iwanami Shoten, 2008), 90-97. 
Chinese goods. ${ }^{26}$ Thus, the expansion of international trade to Southeast Asia occurred at a moment when changes in Japanese taste happened to coincide with the types of ceramics being produced in Vietnam.

Most of the Vietnamese ceramic tea utensils imported to Japan arrived in the first half of the seventeenth century via red-seal trading ships (朱印船), ${ }^{27}$ which suggests active trade between Vietnam and Japan. It is important to note that the ceramic tea bowls in category $\mathrm{K}$ in Figure 3 were manufactured to order. Produced in Vietnam, they had features different from products made for the domestic market. The traditional Vietnamese bowl is flare-shaped, but these ceramics are tube-shaped. Tube-shaped tea bowls, such as Sino ceramics, Oribe ceramics, and Kyo ceramics, were popular in Japan at the time. Furthermore, these tea bowls reflected other cultural trends in Japan, including an intentionally skewed circle and the Wari-kodai (split foot) base.

As Figure 3 shows, the tea bowls in category $\mathrm{K}$ are subdivided into categories $\mathrm{K}_{1}$ and $\mathrm{K}_{2}$, and the water jugs are divided into categories $\mathrm{B}, \mathrm{C}$, and $\mathrm{D}$. The differences between categories $\mathrm{K}_{1}$ and $\mathrm{K}_{2}$-like those between categories B, C, and D-result from different production sites. At that time, northern Vietnam had two major pottery-producing centers, Bát Tràng and Hải Dương. Category $\mathrm{B}$ water jugs were carved products of Bùi Phú Đa in Bát Tràng village (鉢場 社裴富多造). By contrast, category D strictly retained traditional Vietnamese elements. Scholars believe that category $\mathrm{B}$ and $\mathrm{C}$ water jugs were produced in Bát Tràng, and category D in Hải Dương. As for tea bowls, category K1 tea bowls were extremely detailed, while category $\mathrm{K} 2$ tea bowls reflected a Vietnamese cultural influence in their ornamentation. At present, the authors believe that category $\mathrm{K}_{1}$ tea bowls and category $\mathrm{B}$ and $\mathrm{C}$ water jugs were produced in Bát Tràng village, while category $\mathrm{K} 2$ and category $\mathrm{D}$ were produced in Hải Dương Province.

The production of ceramics to order for the Japanese tea ceremony primarily took place in northern Vietnam. In particular, Bát Tràng villagers produced ceramics under very strict supervision and were instructed by a person with a comprehensive knowledge of Japanese preferences. This suggests that there was a special intermediary between Bát Tràng village and its Japanese customers in the first half of the seventeenth century. In fact, documents from Bát Tràng village record that one Japanese family had an intimate connection with the Nguyễn clan of Bát Tràng village in the seventeenth century, as the following section explains.

\footnotetext{
26 Tani Akira, A Study of Tea Ceremony Archives (Kyoto: Tanko-sha, 2001), 199.

27 Nagatsumi Yoko, Tokugawa Shogunate-licensed Trading Ship (Tokyo:Yoshikawa Kobunkan, 2001).
} 


\section{International Activities of the Nguyễn Clan in Bát Tràng Village}

In the seventeenth and eighteenth centuries, Bát Tràng village produced as many as six imperial scholars, two of whom were members of the Nguyễn clan. Extant genealogies of the Nguyễn clan provide information about the development of Bát Tràng pottery village and the activities of Nguyễn clan members who were very involved in both international trade and Vietnamese governance at the local level and beyond.

Figure 4 presents a genealogy of the Nguyễn clan during the sixteenth to eighteenth century based on 阮族家譜實錄 (Nguyễn tộc Gia phả Thực luc, hereafter: Thực luc ). ${ }^{28}$ According to this genealogy, before the progenitor Nguyễn (whose posthumous Buddhist name is Phúc Trí), the Nguyễn clan had already lived in Bát Tràng village for generations. However, when Nguyễn Bảng (阮牓) edited the first edition of the genealogy in 1686, his clan had already lost detailed information on the period prior to the sixteenth century. Relatively clear information is provided only from the generation of Nguyễn Ấn (阮印) onward. According to this genealogy, Nguyễn Ấn migrated to Nghệ An Province in 1595 when he was eighteen years old and returned to Bát Tràng village ten years later. He may have migrated south to take refuge from the war in the Red River Delta between the Mạc and the Restored Lê Dynasty. He returned home after the Red River Delta had re-established peace with the victory of the Restored Lê Dynasty.

After Nguyễn Ấn died, his clan gradually developed its economic power through the pottery trade and gained social status in Bát Tràng village. Nguyễn Ngôn (阮言), Nguyễn Ấn's son, passed his provincial examination in 1654 and became Trùm trường (愽長) in the village. Once, when someone who came to Bát Tràng village to buy a bowl had lost his money, Nguyễn Ngôn searched for the money and returned it to the buyer. ${ }^{29}$ Nguyễn Bảng (阮牓), the second son of Nguyễn Ngôn, passed the provincial examination in 1670 and reached the

阮族家譜實錄 Nguyễn tộc Gia phả Thực lucc, VHv.1349, Han Nom Institute, Hanoi. Several genealogies of the Nguyễn clan in Bát Tràng exist. For instance, Viện Việt Nam học và Khoc học Phát triển has another version of a genealogy of the Nguyễn clan, and Phan Đại Doãn uses this version to study this clan. For details, see Phan Đại Doãn, "One VietnameseJapanese Family of the 17th Century through Examination of Genealogy of Nguyễn Family in Bát Tràng Village," in Japan-Vietnam Interchange History in the Early Modern Period: Japanese Town, Pottery, eds. Sakurai Kiyohiko and Kikuch Seichi (Tokyo: Kashiwa-shobo, 2002), 89-93. However, Thức luc has the most detailed historical information about the seventeenth and eighteenth centuries. The first edition of this genealogy was compiled in 1686 by Nguyễn Bảng, and it was supplemented by Nguyễn Thượng in 1728. It was revised again in the Nguyễn Dynasty period.

29 Nguyễn tộc Gia phả Thực lục, VHv.1349, 12, Han Nom Institute, Hanoi. 


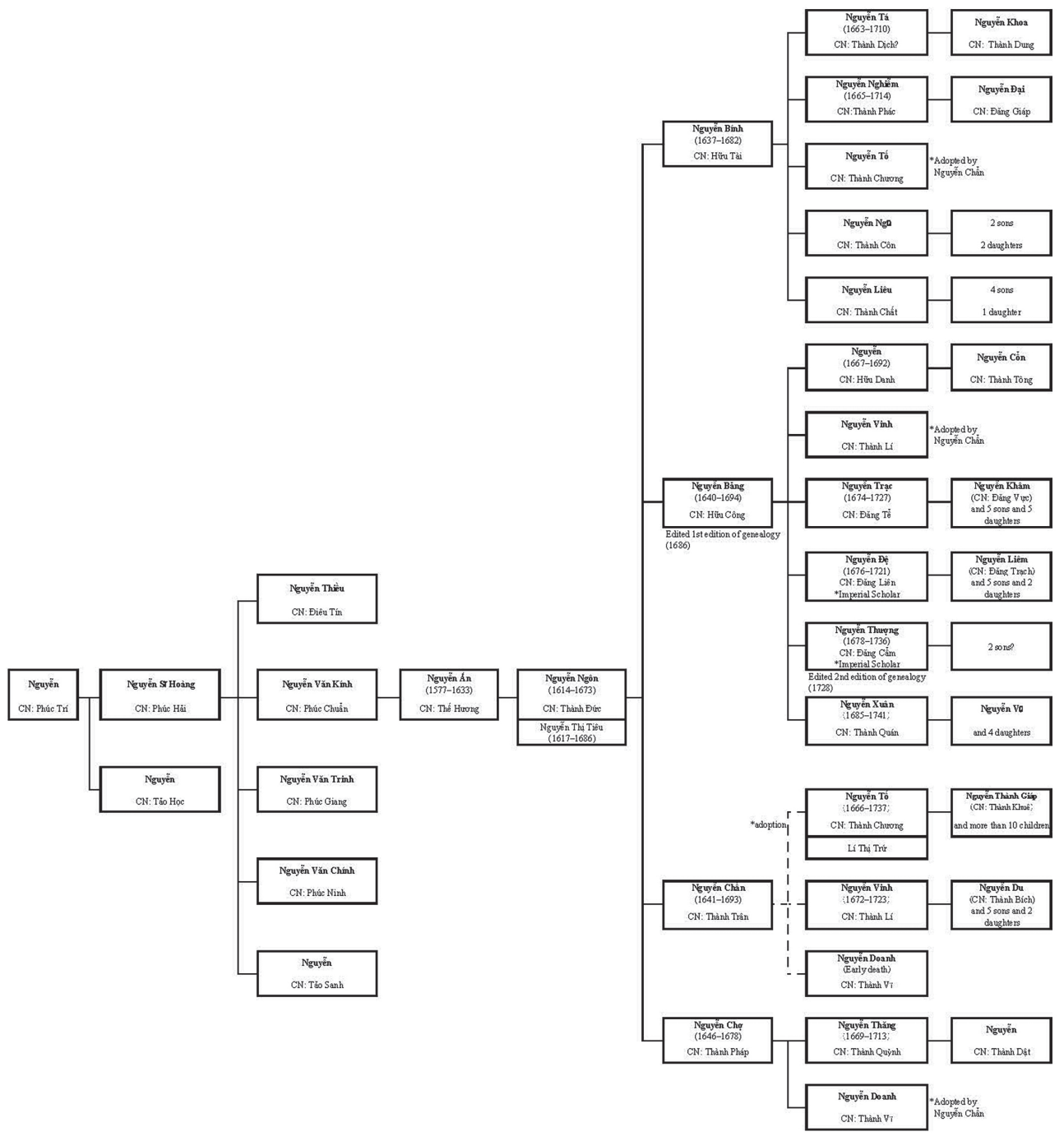

FIGURE 4 Genealogy of the Bát Tràng Nguyễn clan ( $c N=$ clan name $)$.

SOURCE: NGUYỄN TộC GIA PHẢ THỰC LỤC, HAN NOM INSTITUTE, VHV.1349.

rank of Trí huyện (知縣, District Governor) in 1684. During his official service, his four sons apart from Nguyễn Trạc (阮擢) were studying at Hanoi to prepare for the imperial examination, and Nguyễn Bảng's wife earned their living expenses through pottery sales. ${ }^{30}$ Nguyễn Ngôn and Nguyễn Bảng corrected

$30 \quad$ Ibid., 25 . 
several hundred books about Confucianism, examinations, and medicine. ${ }^{31}$ Nguyễn Bảng's two sons, Nguyễn Đệ (阮第) and Nguyễn Thượng (阮尚), passed the imperial examination. In short, the Nguyễn clan gained enough economic power through pottery manufacture to support its members as students and officials over several generations.

From the late seventeenth century onward, when the pottery trade enabled the Nguyễn clan to go into politics, the clan became active on the international level through the branches of Nguyễn Bính (阮炳) and Nguyễn Chẩn (阮賑). For instance, Nguyễn Bính passed the provincial examination in 1657 and worked as a translator in the northern border area between Vietnam and China. After that, he became the Huyện thừa (縣丞, Vice District Governor) in the Red River Delta. ${ }^{32}$ It is notable that the Nguyễn clan produced the eunuch Nguyễn Chẩn. He did not enter into his career because of poverty, as the Nguyễn clan had considerable economic power. According to Thực lục, in 1652, when Nguyễn Chẩn was twelve years old, Hoan quạn công (驩郡公) recommended him to the Trịnh Lord, and he began to work in the financial section of the Trịnh Court, lodging with the Chinese translator Nguyễn Thế Tân (阮勢濱). As a result, he became a financial bureaucrat who was well acquainted with the Chinese language. ${ }^{33}$ When a Chinese trading ship was wrecked, he took a Chinese girl into his home to teach her the Vietnamese language. It might be inferred from these facts that people from the Nguyễn clan in the seventeenth century routinely came into contact with Chinese and foreign traders through the pottery business and thus were appointed by the Trịnh Lords as ambassadors to foreign countries. ${ }^{34}$

In fact, Nguyễn Chẩn had close connections with not only the Chinese, but also the Japanese. He adopted three sons from his brothers. Nguyễn Tố (阮做), his eldest adopted son, married Lý Thị Trứ (理氏著), a granddaughter of Wada Rizaemon (和田理左衛門). ${ }^{35}$ Rizaemon was an influential merchant from northern Vietnam whose name frequently appears in foreign historical

31 Ibid., 12, 25 .

32 Ibid., 21.

33 Ibid., 74. "Hoan quạn công"s is a peerage title. His name is obscure. According to the Authentic Genealogy, his birthplace is Tiêu Thủy village in Yên Phong district (now in Văn Môn village, Yên Phong District, Bắc Ninh Prefecture?). According to Thực lục, Nguyễn Thế Tân's birthplace is Nội Duệ village, Tiên Du District (now in Tiên Phương village, Chương Mỹ District, Hanoi City).

34 Ibid., 75 .

35 Ibid., 90. 
documents. ${ }^{36}$ According to Thư luc, Rizaemon and his family participated in the sea trade and also cast firearms. He was awarded an official naval post for his achievements in promoting national growth. His son (name unknown) was also given the peerage title of Trung Lộc hầu (忠祿侯), and Nguyễn Bính passed away at his house in $1682 .{ }^{37}$ From 1627 to 1672 , the Trịnh Lords battled intermittently with the Nguyễn Lords who governed Cochichina, and both camps used a great number of firearms in this battle. It may be inferred that Rizaemon and his family made an enormous fortune by selling firearms to the Trịnh Lords during this period.

After the sixteenth century, the Japanese founded towns across Southeast Asia, backed by the abundant silver supply and the demand for raw silk, but the closed-door policy of the Tokugawa Shogunate led to their gradual decline from the 1630 on onward. Some Japanese merchants remained in Southeast Asia, and Wada Rizaemon was one of them. He launched ships bound for Makassar, Luzon, and Siam from the 1640 s to the 1660 , and passed away in 1667 in northern Vietnam. ${ }^{38}$ His period of activity coincided with that of Nguyễn Ngôn and his sons. In addition, Wada Rizaemon probably lived close to Bát Tràng village, as in $165^{\circ}$ the Trịnh Lords ordered that Portuguese, Dutch, and Japanese people should live at Cần Lương village in Thanh Trì District and use Vietnamese translators. ${ }^{39}$ This village was located on the opposite bank of the Red River from Bát Tràng village. In light of these facts, it is reasonable to conclude that Wada Rizaemon, an international trader, was connected to the Nguyễn clan that provided Chinese translators and foreign negotiators for the Trịnh Lords. It seems likely that Japanese customers placed orders for tea-ceremony ceramics with someone in the Japanese community of Tongkin, and that Wada Rizaemon, an influential merchant in the Japanese community, passed the orders on to Bát Tràng village.

\section{Reconstruction of the Levee in the Seventeenth and Nineteenth Centuries}

Pottery production in Bát Tràng village developed so well that overseas orders began to arrive in the seventeenth century. Meanwhile, sericulture also thrived

36 Iwao Seiichi, Study of Japanese Town in the Southern Sea [Japanese] (Tokyo: Iwanami Shoten, 1987), 80.

37 Nguyễn tộc Gia phả Thực lục, VHv.1349, 21.

38 Iwao Seiichi, Study of Japanese Town, 208; Iwao Seiichi, Continuous Study of Japanese Town in the Southern Sea (Tokyo: Iwanami shoten, 1966), 101.

Fujiwara Riichiro, Studies on the History of South-East Asia (Kyoto: Hozokan, 1986), 237. 
on the dry riverbed area surrounding Bát Tràng village. Đông Cao village, located to the northeast of Bát Tràng village, paid its taxes in raw silk in the $1640 s,{ }^{40}$ which indicates that mulberry cultivation developed not only in Kim Lan village, but more broadly in the dry riverbed area of the Red River from the sixteenth century onward.

The development of sericulture in the Red River Delta was motivated not only by the growth of international trade, but also by internal factors. By the fifteenth century the ground had been protected by levees, so rice-growing was relatively stable, but beginning in the early sixteenth century, cultivation began to extend to land outside of the levee whose level of agricultural production varied..$^{41}$ Periodic famines produced a large quantity of refugees, breeding social unrest in the seventeenth and eighteenth centuries. ${ }^{42}$ Under these conditions, development of the land inside the levee that was suitable for the cultivation of the mulberry advanced rapidly alongside the international commodification of raw silk.

The shortage of arable land inside the levee not only accelerated the development of the dry riverbed area, it also led to frequent land disputes that could trigger conflict between villages. The dry riverbed area was no exception. Land disputes tended to occur frequently in this area, as the topography was subject to change depending on the rise or fall of river levels. According to one inscription, Bát Tràng village had a land dispute with Đông Cao village in the seventeenth century, and the dry riverbed area was a major factor. As mentioned previously, in the early seventeenth century the neighboring villages of Bát Tràng and Kim Lan had a levee on the A line (Fig. 2), which is thought to have been constructed in the Trần Dynasty period. At this stage, both Bát Tràng and Đông Cao villages were located outside the levee. The dispute between Bát Tràng and Kim Lan began when the old levee on the A line was abandoned and a new levee on the B line was built several hundred meters away. Remains of the B line were excavated by Nishimura Masanari in 2004, and he estimated that the $\mathrm{B}$ line levee was in use from the end of the seventeenth century to the nineteenth century. ${ }^{43}$ An inscription from the communal hall of Bát Tràng village recorded the judgments in the land dispute between Bát Tràng and Đông Cao

\footnotetext{
$40 \quad$ Inscription N. 3525-3528, Han Nom Institute, Hanoi.

41 Yao Takao examines the case of Yên Mỹ village, Nam Định Province. See Yao Takao, Politics and Society of Vietnam in the Early Le Dynasty [Japanese] (Hiroshima: Hiroshima University Press, 2009), 217-240.

42 Sakurai Yumio, Formation of Vietnamese "Traditional" Villages (Tokyo: Sobun-sya, 1987), 288-293.

43 Nishimura, Archaeology and Ancient History of Vietnam, 290-291.
} 
issued by the Lê-Trịnh government from 1654 to $1681 .^{44}$ In 1654, when Đông Cao villagers attacked Bát Tràng villagers and toppled the border stone, the levee on the $B$ line already existed between the two villages. The construction date of the levee on the B line is thus earlier than Nishimura's estimate by thirty to forty years. ${ }^{45}$ Furthermore, the Authentic Genealogy recorded that the levee in Thanh Trì District, on the western bank of the Red River opposite Bát Tràng, was twice breached by flooding in 1630 and 1632 . Considering these facts, it seems likely that a series of riverbank collapses in the 163 os forced the Lê-Trịnh government to take swift measures, and the levee on the B line was constructed before 1654 .

When the levee on the B line was constructed, nearby villages, apart from Bát Tràng, were included within the land protected by it, and the new levee became a border between the villages. However, it also triggered land disputes. Land cadasters from the Nguyễn Dynasty of the early nineteenth century provide contradictory descriptions of village borders. According to the land cadaster of Bát Tràng village, its east side "borders on Đông Cao village with the national levee (the levee on B line)." That is to say, Bát Tràng village insisted that the levee on B line was on its eastern border. On the other hand, the land cadaster of Đông Cao village claims two parcels of dry riverbed land called Bay Văn (a mulberry field in the dry riverbed measuring about 3,6oo $\mathrm{m}^{2}$ ) and Chưởng Thuyền (a crop field in the dry riverbed area measuring about 7,200 $\mathrm{m}^{2}$ ) as the village's own territory. These areas were contested between the two villages. After Bát Tràng village brought an action in court following an attack by Đông Cao villagers in 1654, Đông Cao village, which lost the case, repeatedly appealed the court's ruling on the ownership of the dry riverbed ground. Finally, in 1681, the Trịnh lord ordered the Grand Defender of Kinh Bắc Province to erect a border stone on the B line levee. This border stone was recorded in the land cadaster of Bát Tràng village, but not in the Đông Cao cadaster.

The dispute continued throughout the second half of the seventeenth century. In a series of decisions recorded in the inscription, the judiciary of the Lê-Trịnh government consistently took the strong stand that all of the dry riverbed ground neighboring Bát Tràng village belonged to it and not to Đông Cao village, thus allowing Bát Tràng village to win the case. Nevertheless, despite repeated judicial orders, Đông Cao village did not cease cultivating these areas until the early nineteenth century. ${ }^{46}$

44 Inscription N.3525-N.3528, Han Nom Institute, Hanoi.

45 Ueda asked Nishimura about this issue. Nishimura replied that it was possible that the levee could have been constructed half a century earlier, because his archaeologically grounded estimate of the date was a very modest one.

46 This lawsuit between two villages is a very important case study for examining autonomy among the Red River Delta villages, although the topic exceeds the scope of 
The fact that Đông Cao village kept insisting on its proprietary rights over the contested land deserves attention. It seems likely that this was related to the reconstruction of the levee. As mentioned above, the levee's location had moved from the A line to the B line between 1632 and 1654, and most of the territory of Đông Cao village was within the levee as a result of this reconstruction. However, it seems likely that the construction of the new levee left part of the village's territory outside the levee area, thus dividing Đông Cao village. The administrative branch of the Lê-Trịnh government allowed Bát Tràng village to take ownership of this remaining ground and established a new border on the reconstructed levee. Đông Cao village viewed this decision as unreasonable, and its villagers protested violently.

The simple demarcation of a line by the Lê-Trịnh government led to a longterm land dispute between Bát Tràng and Đông Cao villages from the second half of the seventeenth century. According to the land cadaster of Đông Cao village in the early nineteenth century, the main industry of this village was rice cultivation, apart from about 1 mẫu $\left(3,600 \mathrm{~m}^{2}\right)$ of land devoted to sericulture. Perhaps as a result of the reconstruction of the B line levee, which allowed Đông Cao village to be located within the levee, this village gradually shifted toward rice cultivation. However, the Red River changed its course in the first half of the nineteenth century once again, leading to changes in topography and the need for an administrative reorganization of the villages on the dry riverbed. ${ }^{47}$

It is not clear when the levee moved from the $B$ line to the $C$ line, but a map (see n. 47) indicates that this certainly occurred before the $1860 \mathrm{os}$. At present, it is thought to have happened in the 1820s-30s, because various changes were concentrated in this period. The most important change was that Đông Cao village merged with Bát Tràng village. Before this administrative consolidation, Đông Cao and Bát Tràng villages were independent administrative units called $x \tilde{a}$ (社). According to one old villager, Đông Cao village was absorbed by Bát Tràng village in 1836 . At this time, the former territory of Đông Cao (東泉) was renamed Giang Cao (江泉) and became part of the new Bát Tràng village. In fact, the place name Giang Cao remains xom or làng in present-day Bát Tràng village. Đông Cao village existed as an administrative unit at least until 1805, when the land cadaster of Đông Cao xã was edited by the Nguyễn Dynasty.

this paper. Concerning the autonomy of the Red River Delta villages, see Ueda, "Local Administration."

47 According to one map of the area around Kim Lan village and present-day Văn Đức village, supplied to Ueda by Nishimura, the B line levee had collapsed in 1860, if not earlier. Nishimura's source for this document remains unknown; perhaps it was a district official's report for Thuận An Prefecture. 
However, the maps contained in Đồng Khánh Địa dư chí, edited in 1886, do not show Đông Cao village. ${ }^{48}$ This agrees with the statement of the Bát Tràng villager. Furthermore, according to one old villager in Đông Dư village, the Buddhist temple in present-day Đông Dư village used to be several hundred meters further west, but it was moved to its present position in 1821 because it was badly flooded. There is a monumental inscription from the same year in front of this temple. Thus, it seems that the flood damage in the 1820 s was considerable, breaking part of the B line levee south of Kim Lan, and hence the $\mathrm{C}$ line levee was built.

The $\mathrm{C}$ line levee, constructed in the first half of the nineteenth century, is characterized by having a wider retarding basin than the previous levees. It was the easternmost of the levees, as seen from our present archaeological and documentary examination. Đông Cao and Xuân Quan villages were located outside of the new levee. It is thought that the administrative unification of Đông Cao and Bát Tràng resulted from the construction of the new levee. Hence, this levee was constructed before 1836 .

The C line curved eastward between Đông Dư village and Đông Cao village, leaving a broad area along the riverbank that included some villages. This shows that the builders of the levee were aware of the repeated levee crevasses at neighboring Bát Tràng and Kim Lan villages and determined to secure the area from flood, even though this meant sacrificing some villages. This plan reflects concerns different from those that motivated the placement of the $\mathrm{B}$ line levee. The B line levee included many riverside villages, such as Đông Dư, Đông Cao, and Kim Lan, within the levee. The B line levee was mainly intended to protect the riverbank villages that were established by the development of the sericulture economy in the context of the growth of trade. Thus the B line levee was positioned on a course comparatively near the Red River.

A similar policy change can be inferred from the levee construction at present-day Phụng Châu village (Chương Mỹ District), where the bordering Đáy River forks from the Red River north of Hanoi. According to the inscriptions recording lawsuits from 1674 to 1766 in this village, a new levee was constructed for the Đáy River in 1728. This levee was intended to prevent inundations of river water in order to expand rice cultivation during the wet season. However, in the following year, river water from the Đáy did invade during the wet season and it extended the flooded area into the levee. As a result, the construction of this levee did not increase agricultural production in the area it was meant to protect, it only increased the problem of draining off inland water. In the early nineteenth-century land cadaster of the Nguyễn Dynasty, this village was still

48 Ngô Đức Thợ, Nguyễn Văn Nguyên, and Philippe Papin, eds., Đồng Khánh Địa dư chí, 3 vols. (Hanoi: Nhà xuất bản Bản đồ, 2004). 
a one-crop area in the dry season, and the levee constructed in the eighteenth century had been abandoned. To this day, the village of Phụng Châu has not constructed a large-scale levee. When central Hanoi is in danger of flooding, the water level of the Red River is lowered by draining water into the Đáy River. Therefore, a large-scale levee has intentionally not been constructed on the west bank of the Đáy River.

Comparing the levee policy of the Lê-Trịnh government in the seventeenth century with that of the Nguyễn Dynasty in the nineteenth century, it is clear that the latter obviously had a cross-jurisdictional viewpoint. Given the positioning of the levees constructed in the Lê-Trịnh government period, the builder seems to have intended to protect the newly established villages and immediately increase the rice yield. However, in the long term, this policy led to a vicious circle of further rises in the water level and the increasing danger of levee crevasses due to receding riverbanks and the consequent shrinking of the retarding basin. By contrast, the levee policy of the Nguyễn Dynasty limited the potential for flood damage by creating a wide retarding basin. It is evident that the administrators of the Lê-Trịnh government had some understanding of riparian engineering, in light of the national levee policy in the nineteenth century. Sakurai Yumio maintains that the cross-jurisdictional levee network in the Red River Delta was constructed in the fifteenth century, whereas the preceding discussion suggests that levee construction in the eighteenth century was on an ad hoc basis. Both the Trần Dynasty and the Lê Dynasty played an important role in connecting individual levees, and as a result a large-scale levee network was completed. However, it seems that the administrators, especially those of the Lê-Trịnh government, were unaware that confining the river to a narrow channel would lead to an increase in water levels. Constructing a levee closer to the river facilitated the rapid development of the dry riverbed area during the "Age of Commerce," but it accelerated the rise of the Red River.

\section{Conclusion}

This paper has examined the construction of the Red River levees and the development of the dry riverbed area as examples of land use in the neighboring villages of Kim Lan and Bát Tràng. Kim Lan village was established in the ninth century, and it initially relied on pottery and sericulture. The age of Bát Tràng village remains unknown, but it was established as a pottery village from at least the fourteenth century. The use of the dry riverbed area before the fourteenth century was limited due to frequent flooding, and rice cultivation was very difficult. So the main uses of the riverbed area were pottery manufacture and sericulture. 
However, the development of trade and the shortage of levees inland spurred the rapid development of sericulture in the riverbed area from the fifteenth century onward. This development led to the appearance of new villages and settlements that were based on sericulture and dry-season rice cultivation. The international activity of Bát Tràng's Nguyễn clan members indicates that this development was connected with international trade. Meanwhile, the development of the riverbed area caused frequent land disputes between villages, and agriculture was precarious due to the riparian setting. This was part of the reason for the social unrest in the Red River Delta society in the seventeenth and eighteenth centuries, and it prompted the Lê-Trịnh government's aggressive construction of levees to protect villages. The new levees were designed to stabilize the land and increase agricultural production. It may be assumed that many private levees were also constructed, which would have further accelerated the rise of water levels in the Red River and its branches.

Sakurai argues that an integrated flood control system in the Red River Delta had almost been completed by the early period of the later Lê Dynasty. The investigation in this paper shows that the formation of levee networks was a long and complicated process. The neighboring villages of Kim Lan and Bát Tràng benefited from the construction of a levee during the Trần Dynasty period. However, this levee was not a permanent solution and it has required repeated reinforcement until the present day; in addition, when it failed, its position changed according to the demands of land use. Furthermore, Sakurai claims that from the early period of the later Lê Dynasty onward, the area west of the Đáy River was maintained as a dry riverbed to protect the capital Hanoi. However, this paper shows that the Lê-Trịnh government and the Nguyễn Dynasty together constructed a considerable number of levees. The area west of the Đáy River only became a dry riverbed during the nineteenth century. In general, levee construction in the seventeenth and eighteenth centuries tended to make the retarding basin (or dry riverbed) more narrow - a consequence of the haphazard development of the riverbed area. In the Red River Delta, an integrated flood control policy was not enforced until the early nineteenth century, during the Nguyễn Dynasty.

In short, the development of a levee network to control flooding, observed by Nishimura, was intertwined with the development of local villages, the transformation of local industries, and the expansion of international trade, as well as social unrest, thus providing a broad window on the establishment of early modern Vietnamese society in the Age of Commerce. 